Authors' manuscript. Reference: Diaz Olvera L., Guézéré A., Plat D., Pochet P. (2016), Earning a living, but at what price? Being a motorcycle-taxi driver in a Sub-Saharan African city, Journal of Transport Geography, Vol. 55, pp. 165-174.

\title{
Earning a living, but at what price? Being a motorcycle taxi driver in a Sub-Saharan African city
}

\author{
Lourdes Diaz Olvera \\ Laboratoire d'Economie des Transports, Université de Lyon (ENTPE, Université Lumière Lyon 2, \\ CNRS), Rue Maurice Audin, 69518 Vaulx-en -Velin Cedex, France. Tel.: +33 47204 7244, \\ lourdes.diaz-olvera@entpe.fr Corresponding author
}

\section{Assogba Guézéré}

Department of Geography, University of Kara, B. P. 43, Kara, Togo. Tel.: +228 90280603 , guezereassogba@gmail.com or guezere1970@yahoo.fr

\section{Didier Plat}

Laboratoire d'Economie des Transports, Université de Lyon (ENTPE, Université Lumière Lyon 2, CNRS), Rue Maurice Audin, 69518 Vaulx-en-Velin Cedex, France.

Tel.: +33 47204 7047, didier.plat@entpe.fr

\section{Pascal Pochet}

Laboratoire d'Economie des Transports, Université de Lyon (ENTPE, Université Lumière Lyon 2, CNRS), Rue Maurice Audin, 69518 Vaulx-en-Velin Cedex, France. Tel.: +33 47204 7741, pascal.pochet@entpe.fr

\section{Abstract}

Motorcycle taxis have become an essential part of the transport sector in an increasing number of Sub-Saharan African cities. An analysis of the way this activity operates in Lomé (Togo), based on field surveys, provides a better understanding of the reasons for the development of this transport mode. The majority of drivers earn enough from the activity to meet their day to day needs and to invest to increase human and economic capital. The arduous working conditions, the impacts on health and the risk of accidents and aggression explain however why 
the activity is perceived as temporary and undertaken for want of anything better. There is a need to identify measures to professionalise the occupation and improve its image, and also find the best way to implement them. The occasionally stated goal of doing away with motorcycle taxis in order to modernize urban transport systems would have negative effects on their livelihoods.

\section{Keywords}

motorcycle taxi driver; earnings; livelihoods; working conditions; health; survey; Lomé; SubSaharan Africa.

\section{Introduction}

The last two decades have seen an unprecedented increase in the commercial use of motorcycles in Sub-Saharan Africa. Motorcycle taxis have a strong presence in rural areas where as a rule the availability of public and private transport has been very limited (Ngabmen and Godard, 1998; Porter et al., 2007). But motorcycle taxis are also an essential part of the transport landscape in an increasing number of cities. In the early 1950s, they existed solely in the Senegalese city of Kaolack (Morice, 1981). They appeared in Nigeria at the beginning of the 1970s, in Yola and Calabar (Ogunsanya and Galtima, 1993; Olubomehin, 2012), before spreading rapidly to more of the country's cities (Oyesiku, 2001). In Benin, they arrived in Porto Novo in the second half of the 1970s and Cotonou in 1981 (Agossou, 2003). The "ville morte" urban strikes at the beginning of the 1990s helped them spread to Douala in 1991 (Sahabana, 2006) and Lomé in 1992 (Guézéré, 2008). But they have also existed since the end of the 1990s in several East African cities (Howe, 2003) and to a lesser extent in southern Africa, for example in Huambo in Angola (Lopes, 2010). The spread of motorcycle taxis in urban areas has speeded up since the beginning of this century, as reported in the scientific literature and the local press. Out of a sample of 203 cities with populations of over $100,000^{1}$,

\footnotetext{
${ }^{1}$ We have put together this list from the Geonames database (www.geonames.org), considering all the cities with a population of over 100,000 when there are ten or less of these, or the ten largest cities otherwise, in each of the 42 states of Sub-Saharan Africa (island states excluded). For each of the 203 selected cities, searches were made on Google and Google scholar (Fall 2014) using a combination of the name of the city with the general names for motorcycle taxis (either in French, English or Portuguese, depending on the country) as well as any local names. The representativeness of these 203 cities is determined by the quality, methodology and date of their population
} 
motorcycle taxis have been reported in 104, located in 25 of the 42 countries of Sub-Saharan Africa.

This success is explained by a wide range of factors (Diaz Olvera et al., 2012; Sietchiping et al, 2012). First, there is the economic and social situation that affects the cities of Sub-Saharan Africa: the economic crisis, the recessive effects of the structural adjustment plans that started to be introduced in the 1980s and massive under-employment, particularly among the young (de Vreyer and Roubaud, 2013). As the job required few qualifications, many poorly educated young people saw motorcycle taxis as an opportunity to earn money (Howe and Davis, 2002; Dorier-Apprill and Domingo, 2004; Meagher, 2013). But the mode's success is also partly due to the failings of urban transport systems: the transport authorities regulate them ineffectively, the major transport companies ceased their activities or are in decline, informal transport is both inadequate and expensive and road networks are often in a very bad state of repair (Cervero, 2000; Chile Love, 1988). Finally, their success is the outcome of their qualities as a transport mode: motorcycle taxis are quick, able to travel on roads that are in poor condition, provide door-to-door services, can be purchased with a very small capital outlay, in some cities in the Niger bend they are able to run on contraband fuel from Nigeria, and their fares are lower than for other vehicles for short distances (Agossou, 2003; Nwagwu and Olatunji, 2012; Kamahunda and Schmidt, 2009).

Nevertheless, attitudes towards motorcycles and their drivers are ambivalent. Although they satisfy a demand that other forms of public transport cannot, in the eyes of the authorities - and the general public too - they are often associated with acts of aggression, not to say violence and delinquency. This ambivalence is particularly marked in those cities which have experienced bloody civil wars. The motorcycle taxi provides unskilled former soldiers with a source of revenue, without calming the fears of a resurgence of past violence (Burge, 2011; Menzel, 2011; Peters, 2007). But the activity's image is not better in places with a more peaceful recent history (Konings, 2006; Meagher, 2013; Sadou, 2007). The real or imagined threat the drivers pose to society is the result of their ability to become mobilised for political or social causes, their solidarity when one of them needs or seems to need help (due to a traffic accident, a vehicle breakdown or a dispute with a customer or a policeman) and the involvement of some in thefts from passengers or attacks on them (Burge, 2011; Simone, 2005). It is further

censuses, all of which are highly variable. Our figures depend on the availability on the web of the local press and academic documents, which varies from one country to another. Motorcycle taxis have no doubt spread even further than these estimates. 
strengthened by the fact that the rise of motorcycle taxis has taken place at best with the "passive complicity" of the public authorities (Amougou Mbarga, 2010: 70). In some cases, this rise has entailed violent confrontations due to the authorities' tendency to try to restrict them to the outskirts or ban them completely from urban areas, as in Kampala (Goodfellow and Titeca, 2012), Calabar (Mahlstein, 2009), Jos and Maiduguri (Meagher, 2013) and Accra (OtengAbabio and Agyemang, 2012).

Even though its efficiency as a mode of transport is open to question and its external effects can be criticised, one can still ask whether the motorcycle taxi is an occupation that prevents individuals from sinking even deeper into poverty or if the job actually improves the living conditions of operators and provides a way for impoverished, poorly educated, city dwellers to escape from poverty. After presenting the empirical material (Section 2), we shall evaluate the economic benefits the operators derive from their activities (Section 3). A consideration of the difficulties they encounter, the arduous working conditions, the impacts on health and the risk of accidents or aggression (Section 4) will allow us to see why the activity is generally perceived as temporary and undertaken for want of anything better (Section 5).

\section{Data and method}

Lomé was one of the first capital cities in Africa where motorcycle taxis appeared, in the early 1990s. Today, they are the dominant form of public transport (2.1). The results we shall present in this paper have been obtained from the set of quantitative and qualitative data collected in 2011-12 (2.2) which, in particular, enable us to reconstruct cash accounts (2.3).

\subsection{The city of Lomé}

Lomé, the administrative and economic capital of Togo, is located in the Gulf of Guinea immediately to the east of Ghana. The city's activities are strongly centred on trade (GervaisLambony and Nyassogbo, 2012), and it boasts a very active seaport through which a variety of products pass to and from the landlocked countries of the Sahel. The conurbation, known as "Greater Lomé", had a population of slightly under 1.5 million in 2010 (Bureau Central du Recensement, 2011). The municipality of Lomé alone is home to almost 840,000 individuals, the rest of the population being distributed between the six peripheral cantons. Urban trips are made extremely difficult by the low density of the road network and its bad state of repair, even 
though a large programme of works to rehabilitate and improve the major roads began in 2010 . Black-top or paved roads are mainly confined to the central districts and the primary network of the inner suburbs. Otherwise, the roads are made of earth or sand.

Household motor vehicle ownership rates are low. In 2011, only 9\% of households in Greater Lomé owned a car, and only $28 \%$ a motorized two-wheeler (PNUD, 2013). Most of the city's residents therefore depend on walking or public transport for their travel. Public transport is currently provided by motorcycle taxis and shared taxis, with the minor presence of a few buses operated by Sotral, a company set up in 2007. Motorcycle taxis first appeared in Lomé during the "unlimited general strike" of November 1992. They are referred to using the local names of oleyias ("are you coming" in Éwé, one of the languages spoken in Togo) or zemidjans or zems (“take me quickly" in Fon, also spoken in Togo).

Togo was one of the first countries to introduce specific regulations for commercial motorcycle transport. Since 1996 these have specified the authorisations that are necessary (in particular the licence issued by the Ministry of Trade, third-party insurance, a vehicle registration certificate and a vehicle inspection certificate), and the operating conditions (the motorcycle must be painted yellow, be fitted with specific number plates, display an identification number, carry no more than a certain number of passengers, and helmet use is compulsory). However, as in most of the cities in Sub-Saharan Africa where there are motorcycle taxis, the local authorities are not able to enforce the regulations.

Membership of a trade union was initially compulsory, and several trade unions were created to organize and regulate the profession. However, the regulations were relaxed in 1999 and membership became voluntary. This flexibility and the drivers' mistrust of unions explain why they have been abandoned by the profession, even though they remain the only interlocutors that are recognised by the authorities. Currently there is no comprehensive formal framework for the internal organisation of oleyias. However, on a day-to-day level, motorcycle taxi drivers, particularly those working full-time, meet in the taxi stations, where they wait for clients (Guézéré, 2012). There are about a hundred taxi stations in the conurbation, near trip attractors, business districts and major intersections. The "members" of the station pay a daily fee that is used to provide minimal facilities and create a professional and social assistance fund which is used, for example, to pay large fines, help drivers in the event of an accident or illness, make a contribution to ceremonies that involve its members, etc. The other drivers operate freely, cruising for clients or parking in areas that are not yet occupied by motorcycle taxi stations. 
The number of motorcycle taxis is difficult to estimate as there is no official count. There seem to have been approximately 66,000 in 2006 (Guézéré, 2008) and this figure may have risen to 90,000 in 2011, according to estimates from a trade union official who was interviewed for this study. Due to the absence of a comprehensive travel survey we are also unable to accurately estimate modal split and thus measure their current role in urban transport supply. However, the survey of public transport users undertaken as part of this study of motorcycle taxis shows they are the dominant type of public transport within the conurbation: four out of five of the trips the individuals were making when they were intercepted for the survey involved the use of an oleyia, either as the sole mode of transport (two out of three) or combined with walking or other modes (mainly shared-taxis) ${ }^{2}$.

\subsection{The empirical material}

Our fieldwork was conducted at the end of 2011 and the beginning of 2012 and was in three parts: a questionnaire survey of 1228 public transport users, a questionnaire survey of 147 motorcycle taxi drivers, and 19 semi-directed interviews of drivers providing this service and other stakeholders. This paper is essentially based on the last two of these.

The questionnaire administered to the drivers covered eight topics: socio-economic profile, organisation of the activity and remuneration, characteristics of the vehicle owner (in the case of drivers who do not own the motorcycle), characteristics of the vehicle and operating expenses, regulations, safety, relations with institutions and, finally, opinions on the occupation and its future. A last section allowed the drivers to express themselves freely.

In view of the lack of statistical data on the number of motorcycle taxis and their distribution, we divided the Lomé conurbation into zones, in order to ensure that our sample achieved good spatial coverage and reflected the diversity of practices among motorcycle taxi drivers. This zoning takes account of the main trip generators and activity locations (principal markets, port area, administrative centre, university, hospital, etc.), public transport connection points and residential areas. Ten zones were identified, and zem stations or stopping points were chosen in each of them in order to randomly select our respondents and increase the chances of having zem drivers that illustrate a wide range of situations (Figure 1).

\footnotetext{
${ }^{2}$ For a comprehensive analysis of the role of motorcycle taxis in mobility in Lomé, see Diaz Olvera, L. et. al. (in press, accepted manuscript).
} 
The questionnaires were administered in French or Éwé by six trained survey officers, mainly from Monday to Friday during off-peak hours (9 a.m. -12 p.m.; 2 p.m. -4 p.m.), in order to ensure respondents were available and receptive, and thus limit selection biases and data inaccuracies (Mutiso and Behrens, 2011). Drivers working at less busy times, for example the evenings or Sundays, were also surveyed. To limit refusals due to the possibility of losing clientele during the 30 or 35 minute interview, the driver received compensation of $300 \mathrm{CFA}$ francs, which is equivalent to the price of two "average" rides, at the end of the interview.

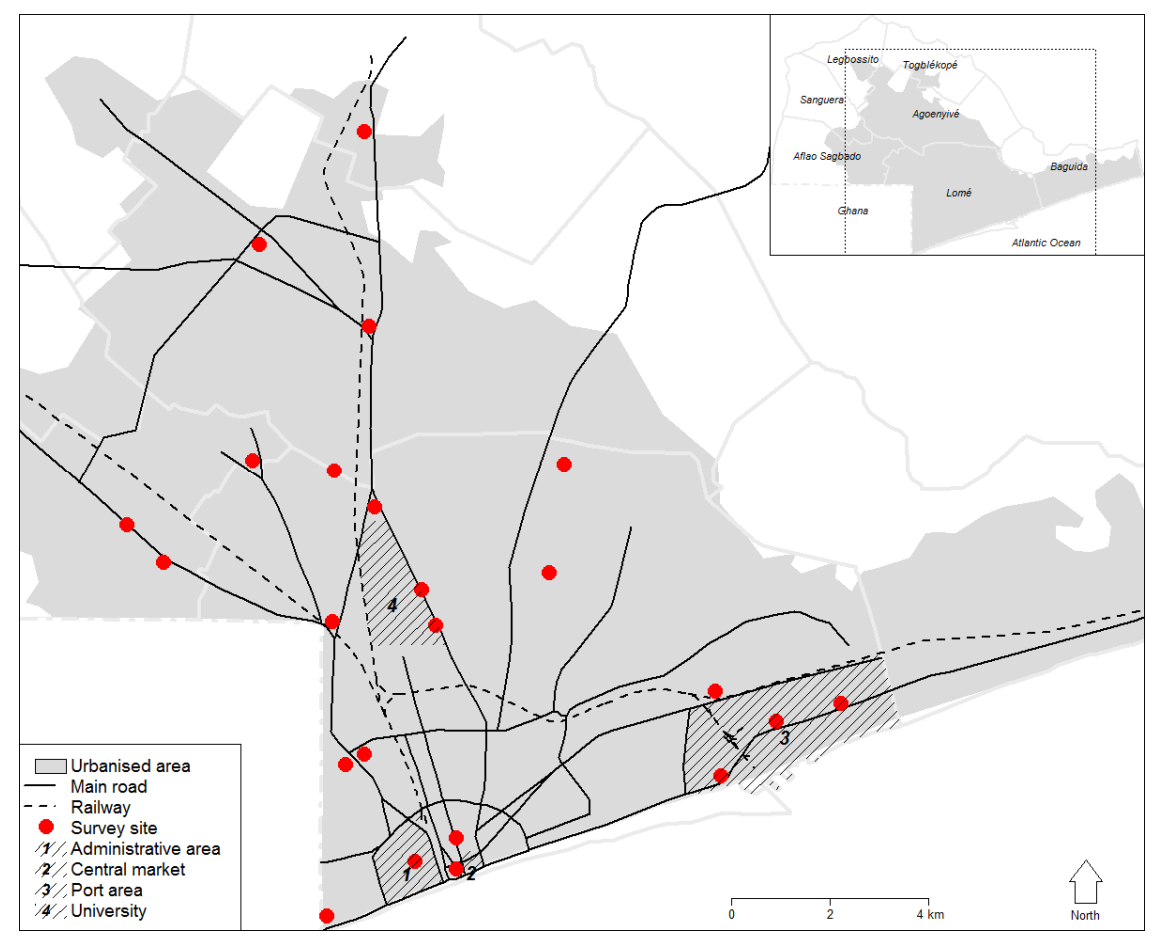

Figure 1. The conurbation of Lomé and the sites where motorcycle taxi drivers were surveyed

Semi-directed interviews were conducted with 12 drivers, 4 individuals who rented out motorcycles to drivers, the leader of a professional grouping and two high-ranking officials from the Ministry of Transport. The topics that were broached with drivers essentially related to their personal history and career, the organisation of their work, its inherent hazards (breakdowns, accidents, attacks), their revenue and expenditure, their relationships with other drivers, the owner of the vehicle and the authorities, and their past and future in the activity. In the case of owners who did not drive the motorcycle themselves, particular attention was paid to their reasons for investing in motorcycle taxis, the contract and their relations with the driver (hirer) and their revenue and expenditure. The topics covered with the institutional stakeholders related to the regulation of zems and its enforcement, the role of motorcycle taxis in the urban 
transportation system, the organisation of the occupation, and the outlook for motorcycle taxis both as a mode of transport and a provider of jobs.

\subsection{The reconstruction of the operator's accounts}

As in many African cities, Togolese transport micro-enterprises do not keep written accounts of their activity, one exception being Ghanaian motorcycle taxis which keep daily records of their income and expenditure (Oteng Ababio and Agyemang, 2012). Along with noncompliance with administrative and regulatory formalities, the small proportion of businesses which take on bank loans, the fact that training is received "on the job" and the lack of social protection, this is one of the characteristics of transport enterprises belonging to the informal sector of the economy (Cervero, 2000; Dimitriou and Gakenheimer, 2011).

Informal firms have a short-term approach to finance, and the concept of amortising capital has no relevance to them (SITRASS, 2001). The aim of the micro-entrepreneurs is for their activity to provide them with "at least balanced income and expenditures (i.e., that they are solvent) and, if possible, some flow of surplus cash" (SITRASS, 2001: 7). Any liquidity surplus has two potential uses: first, it can provide the entrepreneur's personal income, and second, it can be used as "a surplus with which to replenish the cash spent on the investment" (SITRASS, 2001: 10), which makes it possible to calculate the payback period after which the money invested in the motorcycle will be completely repaid. In situations where personal and occupational funds are closely intertwined, it is often difficult to establish which is which.

So, rather than reconstructing operating accounts, what we have done is reconstruct cash flow tables which do not include the capital cost of the vehicle or its amortisation. By deducting expenditure on intermediate consumption (technical services and legal and illegal administrative services) from takings we obtain the added value generated by operating the vehicle, which corresponds directly to the discretionary cash flow (Diaz Olvera et al., 2013). The sums involved can then be divided between the driver and the owner, making it possible to identify their incomes and the payback period.

\section{The upside of the oleyia}

As in other African cities, in Lomé the operation of motorcycle taxis takes a variety of forms, ranging from the purchase of a vehicle to hire out to a driver in order to receive a steady income, 
to the occasional use of a vehicle lent by a friend or family member for several hours a week. These different forms of operation (3.1) provide variable levels of remuneration, and in some cases generate enough income to reinvest in the same activity or other sectors (3.2).

\subsection{Being a driver oneself or hiring a motorcycle}

Having a motorcycle available is the precondition for operating an oleyia service. Chinese motorcycles, which first appeared at the beginning of the 2000's and which cost about 350,000 CFA francs at the time of the survey ${ }^{3}$ (i.e. half the price of the Japanese models that were dominant in the past), have now taken over the market. This is confirmed by the structure of the fleet identified in our survey: 93\% of the motorcycles were Chinese. Their availability has tended to increase the number of motorcycle taxi owners rather than encourage a trend towards concentration, and four out of five owners only have one vehicle. Nevertheless, many drivers hire their vehicle. Four principal categories of players can be identified, depending on whether or not the owner drives the vehicle and the type of contract (if any) that exists between the owner and the driver.

We can divide the owners into self-employed drivers and investors. The oleyia is the sole activity, and therefore the sole source of income, of almost two-thirds of the self-employed drivers. The investors do not drive the motorcycle, but hire it out. In $94 \%$ of cases, hiring out motorcycles is a secondary activity which provides them with an additional income and which constitutes a way of getting a return on their capital.

Hirers fall in two groups, the work-and-pay drivers and the renters. A large number of drivers yearn to own their motorcycle, which has encouraged the spread of so-called work-and-pay contracts, which are usually written. These contracts exist in most cities, for example Accra (Oteng Ababio and Agyemang, 2012), Douala (Ngabmen et al., 2000) or Nigerian cities (Oyesiku, 2001). They differ from the hire-purchase contracts that are sometimes available in other geographical areas with regard to the power the motorcycle owner has over the hirer (Panier, 2012). This power is exercised more easily if the two parties are not connected by close social ties (for example family and friendship ties), as in the case of more than half the workand-pay contracts in Lomé. In exchange for having the daily use of the motorcycle, the driver

\footnotetext{
${ }^{3}$ A vehicle registration fee of approximately 55,000 CFA francs needs to be added to this sum, which covers administrative and insurance costs. These charges are unavoidable, but the motorcycles are almost all registered as private rather than commercial vehicles, as noted by this senior official in the Ministry of Transport: We cannot force owners who have purchased their motorcycle to register as commercial vehicles. They tell you that it's for private use, but the next day you see the same motorcycle being used as a motorcycle taxi.
} 
pays the owner a fixed sum (generally between 10,000 and 12,500 CFA francs per week), for a length of time which is agreed at the outset (on average 72 weeks at the time of the survey ${ }^{4}$ ). Throughout the duration of the contract, the driver must achieve a level of activity that is sufficient to pay the instalments regularly ${ }^{5}$, pay running costs (fuel, maintenance, repairs) and generate his own income. The owner pays the costs that are related to ownership of the vehicle (licences, taxes, insurance). When the contract ends, after having paid a total of between 750,000 and 820,000 CFA francs, i.e. more than twice the purchase cost of the vehicle, the driver becomes the owner of the motorcycle. To be able to meet the terms of the contract, the work-and-pay hirer must use the motorcycle intensively, which makes it almost impossible to do another job at the same time (only $5 \%$ of cases). Such intensive use means the machine is often in bad condition at the end of the contract, with the result that only one in six selfemployed drivers uses a vehicle that was purchased through a work-and-pay contract.

Renters also hire their motorcycle from an owner, but without the possibility of one day owning it. Such arrangements are not always covered by a contract, but when they are it is usually just oral. These situations are therefore essentially informal, agreed on a daily basis, and generally involve the unemployed, tradesmen who are short of work, and students. The owner pays the initial administrative costs and expenditure on major repairs. The renter pays between 2000 and 2500 CFA francs a day to the owner and pays for the petrol, maintenance and minor repairs. Pre-existing close social ties between the owner and the driver (which apply in $83 \%$ of cases) make it possible to come to arrangements regarding the sums and frequencies of payments during periods when business is poor. This 32-year-old driver, who has now become selfemployed after starting to work as an oleyia driver on his arrival in Lomé thanks to the loan of a vehicle from his older brother, explained this situation:

At the end of each week, I gave him 10,000 francs. But sometimes I didn't collect that much so he just took what I could get for him. He didn't make things difficult for me.

Almost three in every five drivers are self-employed, a quarter have work-and-pay contracts and approximately one in six are renters. Apart from their gender - they are all male - the sociodemographic characteristics of these three groups differ considerably (Table 1). Those in

\footnotetext{
${ }^{4}$ The duration of the contract has fallen considerably since the middle of the years 2000 , from slightly under 2 years (Guézéré, 2008) to slightly under 18 months, probably as a result of the arrival of cheaper Chinese motorcycles.

${ }^{5}$ In the case of a missed payment, or even just late payments, the owner may unilaterally break the contract and repossess the machine. Such cases are frequently brought to the attention of the police or even in front of the courts (Panier, 2012).
} 
work-and-pay arrangements and renters are of a similar age, but more of the latter were born in Lomé and they tend to have a higher level of education. On average, the self-employed are older and in an intermediate position as far as their place of birth and educational level are concerned. The majority of drivers in all three groups are household heads, but the proportion is lower among the renters. The characteristics of the investors ${ }^{6}$ differ from those of the drivers: one in three is a woman, and they are also older (43 years of age on average).

Table 1. The sociodemographic characteristics of the motorcycle taxi drivers

\begin{tabular}{|c|c|c|c|c|}
\hline & $\begin{array}{c}\text { Self- } \\
\text { employed }\end{array}$ & $\begin{array}{c}\text { Work-and- } \\
\text { pay }\end{array}$ & Renter & All \\
\hline Mean age (years) & 34 & 30 & 30 & 32 \\
\hline Born in Lomé (\%) & 35 & 26 & 46 & 35 \\
\hline Educational level (\% at least high school) & 40 & 29 & 50 & 39 \\
\hline Head of household (\%) & 99 & 84 & 67 & 90 \\
\hline
\end{tabular}

These categories differ not only in terms of their position in the motorcycle taxi system and their sociodemographic characteristics but also in terms of the income they derive from the oleyia.

\subsection{Earning a livelihood}

The average earnings of the drivers differ considerably from group to group (Table 2). The best paid of the hirers are the work-and-pay drivers, who earn approximately 66,000 CFA francs per month). The average income of renters is considerably lower, standing at 36,000 CFA francs per month, but this is still attractive in a city where the minimum monthly salary was 35,000 CFA francs at the time of the survey, and where many informal sector jobs are paid less than this legal minimum. These sums are particularly significant in view of the fact that the drivers in question do not own their means of production.

\footnotetext{
${ }^{6}$ The investors were not included in the motorcycle taxi drivers survey, but some data was collected indirectly as a result of questions drivers were asked about them.
} 
Table 2. Average income of motorcycle taxi drivers (CFA francs/week)

\begin{tabular}{lcccc}
\cline { 2 - 5 } & Revenue & Inputs & $\begin{array}{c}\text { Rent paid to the } \\
\text { vehicle owner }\end{array}$ & $\begin{array}{c}\text { Weekly } \\
\text { earnings }\end{array}$ \\
\hline Self-employed & 40,200 & 17,800 & --- & $22,400^{*}$ \\
Work-and-pay & 49,400 & 21,500 & 11,300 & 16,600 \\
Renter & 35,900 & 16,500 & 10,500 & 8,900
\end{tabular}

* This amount does not take account of any vehicle depreciation allowances and the cost of capital.

The earnings of the self-employed drivers are considerably higher, of the order of 90,000 CFA francs per month. This average level of income appears to be sufficient to recover rapidly the money they invested in the motorcycle while at the same time generating an income. Assuming that they allow themselves a monthly salary that is equivalent to the average earnings of workand-pay drivers, 70 weeks of work are sufficient to recover all the initial capital (purchase cost and registration charges). If they make do with the income of renters, the payback period is only 30 weeks. The position of investors appears to be even better. They receive, on average, a rent of 43,600 CFA francs per month, which is only slightly reduced by the few expenses they are required to meet (1,000 CFA francs). If this income is allocated exclusively to writing off the purchase and registration costs of the vehicle, the investors could recover their capital in 38 weeks. In the time the contract still has to run, slightly less than nine months, they are still able to earn the net equivalent of the purchase price of a new motorcycle. The data from our surveys do not enable us to reach a reliable estimate of the service life of the machines. However, we can observe that three-quarters of the motorcycles making up the current fleet operated by selfemployed drivers are over 16 months old and almost one third is over 36 months old. In view of this, the mean payback period shows a high rate of return, which means the activity is viable in the long term for self-employed drivers, and even more so for investors.

But these groups of stakeholders are heterogeneous, and average earnings conceal wide variations in incomes. The first thing to note is that individual occupational practices have a marked impact on earnings. For all the categories, night working or long experience as an oleyia driver provides higher incomes (as shown, for example, by Arosanyin et al., 2011 in Zaria). Thus, those self-employed drivers who have been doing the job for three years or less and who only work during the daytime earn less than $60 \%$ of the average. In contrast, the most experienced self-employed drivers who work at least partly in the evenings or at night earn 50\% more than the average. However, it is important to note that these estimates of average earnings relate to situations without difficulties, when the motorcycle does not have a major accident or 
breakdown, and when the driver is not forced to stop working on health grounds. Work-andpay contracts, for example, do not all have a positive outcome, as reported by this 52 year-old driver who has suffered a series of failures:

After the theft [of his first work-and-pay motorcycle], I was out of work for a year, then someone bought me another motorcycle. This employer bought me a Mate motorcycle which he rented out to me under a 1,200,000 CFA franc work-and-pay contract. At the end of the contract the motorcycle was unrepairable and I could not go on using it.

In order to gauge the economic viability of the motorcycle taxi, we need to change timescales and examine the long-term use of the money it generates.

For investors, the rate of return is sufficient to encourage them to buy a new motorcycle, as we were told by a 67 -year-old retired publicly employed technician who was initially attracted by the activity's image as a profitable one, and who went on to offer more motorcycles to rent, or this 38-year-old woman seller of palm wine, who has already had three work-and-pay motorcycles in succession and who explained:

It [operating motorcycles] is a good business because it brings me in money ... it's good, you can't make a loss.

The verdict is more mixed for the drivers. A fifth of the drivers only earn enough to live from day to day and it only covers everyday expenditure, as in the case for this 29 -year-old selfemployed driver with four dependents.

If you are a zem driver, you can eat. You can't have any projects, but at least you will be able to eat.

This proportion is higher among hirers (one in three) and much lower among self-employed drivers (one-ninth, see Table 3). The difference between the categories is mainly due to the length of time they have been driving oleyias (which affects their earnings): five years for the self-employed drivers, a little less than three years for the other two groups. Nevertheless, in all the categories, the majority of drivers earn enough from the activity to envisage a variety of uses for the sums they receive. Some of the money is invested, in human capital first of all, then in economic capital. The projects involving the domestic sphere are less frequent, particularly for renters, fewer of whom have dependents. 
Table 3. Motorcycle taxi drivers' domains of investment (\%)

\begin{tabular}{lcccc}
\cline { 2 - 5 } & $\begin{array}{c}\text { Domestic } \\
\text { sphere }\end{array}$ & $\begin{array}{c}\text { Economic } \\
\text { sphere }\end{array}$ & Education & None \\
\hline Self-employed & 27 & 55 & 66 & 11 \\
Work-and-pay & 24 & 21 & 50 & 32 \\
Renter & 4 & 50 & 46 & 33 \\
\hline Total & 22 & 46 & 59 & 20
\end{tabular}

Domestic sphere: purchase of land, construction of a house, home improvements, marriage.

Economic sphere: purchase of a vehicle, investment in agriculture, trade, or another occupational activity, savings.

Education: tuition fees, cost of uniform, etc. for dependent children or the driver himself.

The strong link between earnings from driving a motorcycle taxi and educational expenses is known to apply in a number of urban contexts (in Cameroon, Nkede Njie, 2012; in Benin and Togo, Aboudou and Sounon Bouko, 2010; in Liberia, Pah Forsther, 2011). It is stronger among self-employed drivers, as a direct outcome of their age and family responsibilities (see Table 1). The emphasis that is placed on the education of the young shows that education still has a positive image and qualifications are still valued, even if they no longer guarantee finding work. This applies even when the driver himself has been unable to find work that corresponds to his professional training. One example is this electrician with four dependent children who has taken one work-and-pay contract after another for several years because he cannot find a job that is in line with his training:

My project is my children. I'm a zemidjan driver [because of them]... my two daughters got to university, my son to middle school. I have not been able to save any money, but what interests me is my children's future.

Investment in productive activities seems to be abandoned by work-and-pay drivers (only one in five). This is however a false impression because in their case, driving a motorcycle taxi is by its very nature for an economic end. At the end of the contract, the driver hopes to become the owner of the machine, if all goes well. Buying an additional motorcycle is also one of the goals pursued by self-employed drivers. More than a quarter of those who have invested in the economic sphere have purchased at least one motorcycle as a result of their earnings.

Working as a motorcycle taxi driver enables individuals to meet day-to-day expenses. Four out of every five drivers spend some of their earnings on improving their own situation and that of their household. Self-employed drivers, who own their own machine, are nevertheless able to undertake more projects, and a wider variety of projects, than hirers. In Lomé, Kigali (Rollason, 
2013), Cotonou (Agossou, 2003; Aboudou and Sounon Bouko, 2010), Ojo (Ogunrinola, 2011) and Accra (Quénot Suarez, 2012), being a motorcycle taxi driver is more profitable than other informal activities. But these higher earnings are in compensation for their difficult working conditions.

\section{The downside of the job}

The most unpleasant aspect of the work is the long working hours which increase the incidence of illness and physical difficulties (4.1). But there is also the need to constantly get around the law and avoid its representatives, even if it means ignoring the rules of road safety or even being very close to committing a common law offence (4.2).

\subsection{Hard work, poor health}

Strong competition between operators means that the profitability of the activity essentially depends on the amount of time devoted to it (Table 4). On average, drivers work six days a week and almost ten hours a day if one includes the time spent waiting for clients at the stations or other stopping points (roadsides, roundabouts, etc.). They drive 8 hours a day, during which time they are exposed to vehicle pollution, noise and accident risk. Those with work-and-pay contracts are even worse off. They are under a great deal of pressure in order to collect the rent for the motorcycle and earn enough to cover their daily living expenses; their days are long, with a mean working day of almost 11 hours ( 9 of which are spent driving), more than 6 days a week.

Slightly more than a third of the operators, irrespective of the category, work after 7 p.m., at least occasionally, when lower competition means they can charge higher fares. Some work at night to be able to combine the oleyia with a day job, but occasional night work also provides a way of making some money in an emergency or on a bad day. Thus, a 26 year-old selfemployed driver stated:

If I have a debt to pay back or if I have an expense to pay, and there are no customers, I work all through the night until day-break in order to pay the debt. 
Table 4. Working conditions of motorcycle taxi drivers

\begin{tabular}{lcccc}
\cline { 2 - 5 } & $\begin{array}{c}\text { Hours in } \\
\text { working day }\end{array}$ & $\begin{array}{c}\text { Number of } \\
\text { days/ week }\end{array}$ & $\begin{array}{c}\text { Driving time } \\
\text { / week }\end{array}$ & $\begin{array}{c}\text { Number of } \\
\text { rides } \\
\text { / week }\end{array}$ \\
\hline Self-employed & 9.4 & 5.4 & 42 & 201 \\
Work-and-pay & 10.8 & 6.3 & 56 & 268 \\
Renter & 9.8 & 5.4 & 43 & 220 \\
\hline Total & 9.8 & 5.7 & 46 & 221 \\
\hline
\end{tabular}

Night working also makes it easier to avoid police checks. But keeping away from busy areas or lighted districts where the police tend to take up position also increases the risk of being attacked. Some operators are very aware of this (see Section 4.2). The activity therefore owes its arduous nature not just to the long working days and the small number of rest days, but also to the specific fatigue caused by night work. To this are added the hazards of daytime traffic and the risk of night-time attacks. The arduous and dangerous nature of the job has an impact on drivers' health.

The drivers often suffer from work-related diseases and conditions. When the respondents were asked to name a maximum of three health problems, they mentioned 2.3 on average. Almost none of them claimed to be in perfect health. The number of reported illnesses increases steadily with the length of their experience, rising from an average of 2.1 illnesses among those operators who have done the job for less than a year, to 2.7 for those who have done it for over 5 years.

By far the most frequent condition is back pain, which affects almost nine out of every ten operators irrespective of the length of their experience (Table 5). This extremely high prevalence, which has also been reported by Konings (2006) among the bendskin drivers of Douala, is the outcome of the combination of long working hours and the poor condition of the roads, as explained by a self-employed driver who also works as a teacher:

The conditions I can mention affect my spine and hip. I didn't have any trouble before, especially not in my hip, I first noticed it after I started. Look at the roads, they are so bumpy, every time I get home I have to apply our renowned Victago ointment. 
Table 5. Percentage of drivers suffering from various conditions

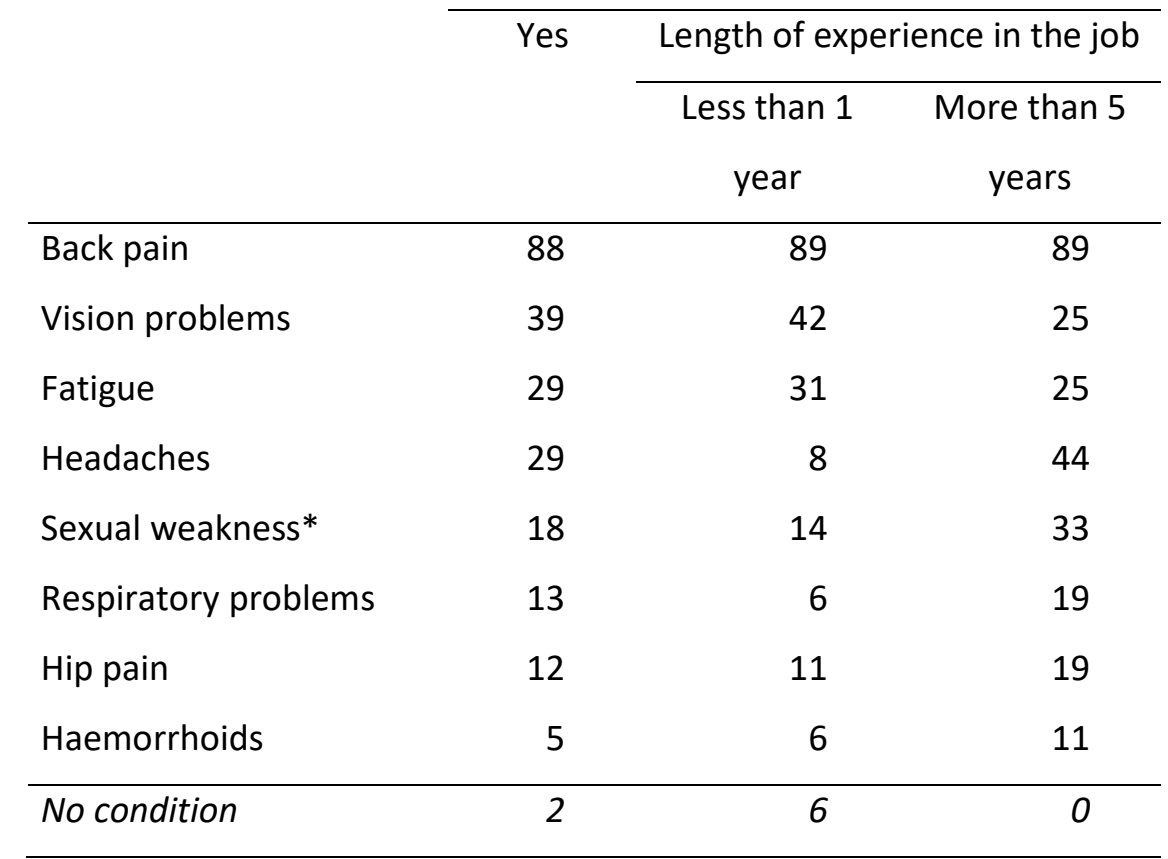

* i.e. erectile dysfunction and/or loss of libido (Guézéré, 2008:355).

Vision problems, fatigue, headaches and sexual weakness were also frequently mentioned (between one and two in every five drivers). Vision problems and fatigue seem more prevalent among the drivers with shorter experience. This may be because they have not had enough experience to be able to adjust to the tempo of work and take preventive or curative measures in time. These conditions also came up frequently in the interviews, and were often blamed on exposure to dust and the sun, as in the case of this 21 year-old renter:

What bothers me most is the dust. Although I have a scarf, I can't use it much because I'm not used to it. So I often suffer from coughs and colds. Or, if I stay for long in the sun, I get headaches.

The effects of the driving environment (damaged roads, pollution, the weather) are particularly marked because the drivers are exposed to them for long periods and repetitively, because of the intensity of their work. The latter also has an adverse impact on road safety, due to noncompliance with regulations.

\subsection{Rebels or bandits}

A number of regulatory requirements are directly linked to safety, such as holding a driving licence, wearing a helmet, being insured and complying with the Highway Code. 
In spite of the running of special training courses funded by international organisations, almost none of the drivers have a driving licence (Table 6). It is, of course, true that the occupation of zemidjan driver is facilitated by the fact that it is easier to learn to drive a motorized two-wheeler than a car. But, as is the case in Nigeria (Ogunrinola, 2011; Adetunji and Aloba, 2014), most of the oleyia drivers have only had a very short period of training or none at all, as this 32 yearold self-employed driver explained:

To be honest, I had never been on a motorbike. The first time I rode a Mate motorbike was as a zem driver.

Table 6. Percentage of motorcycle taxi drivers complying with regulatory requirements

\begin{tabular}{lccc}
\cline { 2 - 4 } & $\begin{array}{c}\text { Hold a driving } \\
\text { licence }\end{array}$ & $\begin{array}{c}\text { Often wear a } \\
\text { helmet }\end{array}$ & $\begin{array}{c}\text { Have } \\
\text { insurance }\end{array}$ \\
\hline Self-employed & 6 & 27 & 11 \\
Work-and-pay & 0 & 18 & 58 \\
Renter & 4 & 25 & 25 \\
\hline Total & 4 & 24 & 25 \\
\hline
\end{tabular}

Only one in four drivers often wears a helmet, which is as many as those that never use one. The reasons given for not wearing one were varied: the heat and headaches, the risk of not hearing clients call in the street, a refusal on the part of clients who are afraid of banging their head against the driver's helmet if they brake suddenly, straightforward aesthetic reasons, because "It doesn't suit me" in the words of one respondent. Helmets are also compulsory for passengers, but compliance with this rule is even lower: drivers never have a helmet for the passenger, and the passengers would not be willing to wear one. Such behaviours among drivers and passengers have been identified in a large number of cities (Amougou Mbarga, 2010; Menzel, 2011; Peters, 2007) and it seems that increasing helmet wearing would require strong political will backed up by effective punishment and heavy fines (Sumner et al, 2014).

Almost all the machines are insured during the first year as third-party insurance is required in order to register a motorcycle. After this first year, only some work-and-pay drivers are insured, when the investor wants to protect the vehicle until the end of the contract. The reason given by many drivers for not paying insurance is that the insurers do not honour the contracts: "They claim falsely that they take on responsibilities, but they never honour them if there's an 
accident". "It's money down the drain, no-one is insured if there's an accident". "In Togo, the insurance companies cheat”.

Many drivers also admit to violating the Highway Code. Driving fast or overloaded by carrying either more than one passenger or a passenger plus his/her luggage are seen as ways of increasing earnings: "I often drive through red lights. It's dangerous, but I do it to go fast. I do it to earn more..." (a renter, who has driven an oleyia since arriving in Lomé four years ago); "If there's luggage I put it in front of the motorcycle. I increase the price according to what luggage there is" (a renter, driving his elder brother's motorcycle). Less than one out of every five drivers states that they always refuse to carry cumbersome goods.

The result of these risky behaviours is a high accident frequency. Poor road safety is an adverse consequence of the development of motorcycle taxis which are very strongly criticised by the public authorities and often mentioned in the scientific literature or the press. Our quantitative surveys do not allow us to reconstruct accident statistics, but they do give an idea of the feeling of danger that prevails amongst both operators and users. Eight percent of users had an accident in the year before our survey (Table 7). As one would expect, the rate is higher for drivers (43\%). These figures, which are close to previous estimates for Lomé (Ogalama Yabo et al, 2000; Aboudou and Sounon Bouko, 2010), show no deterioration in the last 12 years. Minor accidents are proportionately more frequent among the operators-because the perception of accidents as more or less trivial makes it easier for them to accept the risks that are taken on a daily basis.

Table 7. Percentage of motorcycle taxi drivers and users who had an accident in 2011

\begin{tabular}{lccc}
\cline { 2 - 4 } & No & Minor & Serious \\
accident & accident & accident \\
\hline Drivers & 57 & 36 & 7 \\
\hline Users & 92 & 5 & 3 \\
\hline
\end{tabular}

The oleyias are not only exposed to danger on the roads, they are frequently perceived as posing a threat to public order, both by the authorities and the general public. This negative image can even be found among some representatives of the occupation, for example one leader of a professional grouping stated the following:

For the slightest reason, they're quite willing to insult and even threaten road users, so we've got to gradually get this out of their head. Just because they think they're social 
outcasts doesn't mean they can vent their anger on other road users who are also frustrated.

Consequently there is a considerable amount of conflict between drivers and passengers, about the price of the ride or the driver's speed, driving style and risk-taking. One out of every five users reported having had a problem of this type with a motorcycle taxi driver in 2011. Nevertheless, they rarely associate oleyia journeys with attacks or thefts (less than one out of every hundred users). However the behaviours of motorcycle taximen can sometimes verge on the criminal. An example is when a driver appears to be the victim of an accident with a car, of police harassment, or having an argument with a user. Under these circumstances, the solidarity within the group comes fully into play and the power struggle takes precedence over compliance with regulations, as in this statement from a work-and-pay driver with five years of experience:

I was attacked by a client. A passing zemidjan pulled in straight away and asked what was happening. I explained that I had given a ride to the man and he had refused to pay. When he saw the first motorcycle taxi driver arrive, then the second and the third, he paid automatically.

This statement also shows that the oleyia driver can sometimes be the victim. Zem drivers feel vulnerable to attacks from their clients, and in 2011 some of them have had either their takings or vehicle stolen ( $7 \%$ of those who work at night, compared with $1 \%$ of those who work during the day). This is why most of them avoid making journeys at night into sparsely populated and poorly lit areas, as noted by Kisaalita and Sentongo-Kibalama (2007) in Kampala. One example is this 26-year-old self-employed driver with six years of experience:

The work is dangerous at night, and I become suspicious. I don't take clients anywhere as in the daytime. I don't go to dark places. You can be held up if you take the risk.

Motorcycle taxis are thus perceived as a source of danger and simultaneously feel that they are at danger themselves. This, in combination with their long working days and health concerns, explains why the occupation is seen as a transitory activity. 


\section{Drivers en route to another occupation}

Being a motorcycle taxi driver is part of a wide variety of career paths, and generally speaking, the drivers would prefer to do the job for a short period.

Some of those who decide to take up the activity are students who do so either to finance the studies, or after they have qualified before they have found a job that is related to their training. This group prefers to rent their motorcycle, as the work involves fewer constraints (Table 8).

Table 8. Previous situation of motorcycle taxi drivers (\%)

\begin{tabular}{lcccc}
\cline { 2 - 5 } & Employed & Unemployed & Student & Total \\
\hline Self-employed & 56 & 30 & 14 & 100 \\
Work-and-pay & 34 & 50 & 16 & 100 \\
Renter & 29 & 29 & 42 & 100 \\
\hline Overall & 46 & 35 & 19 & 100 \\
\hline
\end{tabular}

A second career path consists of men who are looking for work. In Lomé, half of the work-andpay drivers were unemployed before becoming an oleyia, and the proportion is three in every ten for the other categories of driver. In spite of the high rent and the difficult working conditions, becoming a work-and-pay driver provides an unemployed person with a means of survival and the hope of moving up the social ladder by ultimately acquiring a means of production.

Almost half the respondents were in work before driving a motorcycle taxi. The percentage is slightly higher among the self-employed drivers, as it is easier for people who have already worked to purchase a motorcycle. Some of this group have other jobs at the same time, and see the motorcycle taxi as providing a supplementary income, in order to improve their standard of living or help them cope with irregular salary payments, as is the case with this teacher, a 33year-old self-employed driver:

I work in a private school, and as you know private schools don't pay well. There are always arrears. My motorbike means I can't die of hunger.

However most of the recruitment is from the countless trade and service occupations: mechanic, stonemason, electrician, shopkeeper, tailor, cook, etc. The boundary between being in work and being unemployed is frequently ill-defined, and many workers are very episodically employed, 
depending on casual work or orders that are too few and far between, like this self-employed motorcycle taxi driver, who is primarily a joiner:

I chose the zem because my trade is no longer viable. But when friends in the trade get a construction project, they call me and we work together. The income from my motorbike provides just enough to keep my home running.

What emerges from both the interviews and the questionnaire survey is that it is their first occupation that gives them their occupational identity, as the same driver explains:

My decision to drive the motorbike was voluntary, but my family disapproved. It's not right to learn a trade then leave it to drive a zemidjan.

The motorcycle taxi carries a certain social stigma and is seen as a temporary way of earning a living, while making savings in order to return to one's initial occupation under better conditions.

Although motorcycle taximen have followed a wide range of career paths, most drivers refuse to consider the oleyia as a long-term activity (Table 9). Only one in every five drivers wishes to continue in the oleyia sector beyond the short term (half of them as a driver, half as an investor), with some variations from one category of operator to another. The renters are the group with the fewest who see themselves still in the occupation at the end of 2012 and the fewest to consider becoming investors. Work-and-pay drivers, who hope to own their motorcycle in 2014 at the latest, would like to stop driving. While this group is that with the largest number of drivers wishing to hire out their machine to a driver, the proportion is still very low, confirming how difficult it is to move from one category to another (Kisaalita and Sentongo-Kibalama, 2007). Finally, in spite of the fact that their activity seems to be more viable in the long term than the others, the majority of self-employed drivers would nevertheless like to return to their previous activity or change sectors. 
Table 9. Percentage of motorcycle taxi drivers wishing to continue the activity

\begin{tabular}{lccc}
\cline { 2 - 4 } & $\begin{array}{r}\text { Yes, to } \\
\text { end of } \\
2012^{*}\end{array}$ & $\begin{array}{c}\text { Still a driver in } \\
2013 \text { and } 2014\end{array}$ & $\begin{array}{c}\text { Investor, in } \\
2013 \text { and } \\
\text { Self-employed }\end{array}$ \\
Work-and-pay & 68 & 10 & 11 \\
Renter & 46 & 5 & 13 \\
\hline Overall & 64 & 10 & 4 \\
\hline
\end{tabular}

* The survey was undertaken in March 2012.

In spite of the fact that it is better paid than many jobs in the informal sector, the occupation of motorcycle taxi driver is not attractive in the long term. Difficult working conditions, the risks associated with the job, and their impacts on health are obviously partly to blame. But the fact that this relatively unskilled occupation, which is pursued by default and which does not provide a legitimate job that is accepted by society, also plays a part.

\section{Conclusion}

The case of Lomé shows that the motorcycle taxi provides operators with more than mere subsistence. However, the large disparities in earnings between the categories of stakeholders show that all of them do not fare equally well from this extremely competitive activity. Investors, who derive high incomes from their motorcycle in a fairly brief period while escaping from the negative consequences of actually driving, are the main winners. Among the drivers, owning the machine is also a positive factor and the two groups of hirers seem to be the worst off. Because of their experience, or because they work at times when competition is less fierce, some drivers manage to generate an income which provides some hope of escaping from poverty. However, such an escape is made difficult by the relatively impermeable boundaries which separate the categories. Renters live from the activity, generally for a short period; few work-and-pay drivers become self-employed; very few self-employed drivers manage to become investors. The system operates in a way which seems more likely to reproduce existing inequalities than to reduce them.

Progressing within the motorcycle taxi sector is hindered by its poor social image. Motorcycle taxi drivers are seen by society - and frequently even by themselves - as outsiders, on the 
borderlines of legality but seeking legitimacy. They see their job as a temporary one that they do for want of anything better rather than as a "real trade". It is therefore hardly surprising that the operators find it difficult to construct a self-image that is based on the positive characteristics and rewarding nature of the activity.

In Lomé, after decades marked by an absence of public policies in the area of urban transport, the authorities are now counting on the new bus company SOTRAL to act as a "natural" regulator of the market and gradually reduce the dominance of the motorcycle taxi. Nevertheless, demand for motorized transport is present at a variety of spatial scales. SOTRAL's buses serve the major roads with large passenger flows and will not be able to take the place of motorcycle taxis in residential or isolated areas, where passenger flows on secondary roads are moderate or low. The growth of the urban area and the lack of adequate roads both tend to foster the use of motorcycle taxis as a feeder mode to carry passengers from zones with poor accessibility to ones which are better served by high capacity systems. The survival of motorcycle taxis after the setting up of Bus Rapid Transit in Lagos shows that they are able to adapt to the arrival of mass transport systems by spontaneously offering feeder services.

However, laissez-faire policies cannot foster complementarity between conventional public transport and informal transport, or improve the latter's efficiency and reduce its negative externalities (Godard, 2013). It would, in the short and medium term, be possible to introduce some measures to professionalise the occupation and improve its image. Drivers could gradually acquire the basic requirements for the occupation (safety, security and health, quality of service, management skills) through compulsory training for present-day drivers and new entrants, a more appropriate regulatory framework and the enforcement of regulations. At the same time, making it easier for drivers to acquire a motorcycle, for example by organising grouped purchases or providing low-interest loans, would help to create a fairer balance of power between investors and hirers. Such initiatives may, however, be difficult to put in place. The public authorities, at both national and local levels, sometimes lack the ability to design appropriate policies, as well as the resources to enforce them. In addition, groups drawn from the profession, whether associations or unions, could help initiatives of this type, on condition, however, that they are genuinely representative of the profession and are trusted by its members, which cannot be taken for granted.

The occasionally stated goal of doing away with motorcycle taxis in order to "modernize" urban transport systems but also because they are "unmanageable" by the authorities, would have 
serious effects for the residents who use them on a daily basis if similarly-priced alternative modes of transport are not introduced to replace them. The result would be for the drivers to lose their livelihood. In an economy where jobs are scarce, it would be paradoxical to prohibit a labour-intensive activity that generates income. While transport policies in African cities must set out to improve the efficiency of the sector, they must also be part of comprehensive poverty reduction policies.

\section{References}

Aboudou, R., Sounon Bouko, B., 2010. Portée et enjeux des transports marchands à deux roues au Bénin et au Togo. In: Fodouop, K., Tape Bidi, J. (eds.), L'armature du développement en Afrique. Industries, transports et communication. Karthala, Paris, pp. 169-188.

Adetunji, M.A., Aloba, O., 2014. The level of compliance of commercial motorcyclists to traffic rules on urban roads in South Western Nigeria. Journal of Educational and Social Research 4(3), 345-351.

Agossou, N.S., 2003. La diffusion des innovations : l'exemple des zémijan dans l'espace béninois. Cahiers de géographie du Québec 47(130), 101-120.

Amougou Mbarga, A.B., 2010. Le phénomène des motos-taxis dans la ville de Douala : crise de l'État, identité et régulation sociale. Une approche par les Cultural Studies. Anthropologie et Sociétés 34(1), 55-73.

Arosanyin, G.T., Olowosulu, A.T., Oyeyemi, G.M., 2011. Employment generation and earnings in the informal transport sector in Nigeria. International Business and Management 22(2), 139-148.

Bureau Central du Recensement, 2011. Recensement général de la population et de l'habitat. Résultats définitifs. République togolaise, Lomé. http://www.stattogo.org/index.php?option=com_docman\&task=doc_download\&gid=14\&\&Itemid=56 (accessed 7.13.13).

Bürge, M., 2011. Riding the narrow tracks of moral life: commercial motorbike riders in Makeni, Sierra Leone. Africa Today 58(2), 58-95.

Cervero, R., 2000. Informal transport in the developing world. UN-HABITAT, Nairobi.

Chile Love, M., 1988. Industrial land use activity and intra-urban transport demand in Kaduna town, Nigeria. In: Urban Transport in Developing Countries: Which Policies for Our Towns? Proceedings of CODATU 4. Jakarta.

De Vreyer, P., Roubaud, F., 2013. Urban Labor Markets in Sub-Saharan Africa. World Bank Publications, Washington DC.

Diaz Olvera L., Guézéré A., Plat D., Pochet P., 2013. The motorbike taxis in Lomé: who earns what? XIIIth World Conference on Transport Research, Rio de Janeiro, July 15-18, 15 p. https://halshs.archives-ouvertes.fr/halshs01093566 (accessed 1.7.15).

Diaz Olvera, L., Guézéré, A., Plat, D., Pochet, P., (in press, accepted manuscript). Improvising intermodality and multimodality. Empirical findings for Lomé, Togo. Case Studies on Transport Policy http://dx.doi.org/10.1016/j.cstp.2015.10.001.

Diaz Olvera, L., Plat, D., Pochet, P., Sahabana, M., 2012. Motorbike taxis in the "transport crisis" of West and Central African cities. Echogeo (20).

Dimitriou, H.T., Gakenheimer, R., 2011. Urban Transport in the Developing World. A Handbook of Policy and Practice. Edward Elgar Publishing, Cheltenham.

Dorier-Apprill, É., Domingo, É., 2004. Les nouvelles échelles de l'urbain en Afrique. Vingtième siecle. Revue d'histoire (1), 41-54. 
Gervais-Lambony, P., Nyassogbo, G.K., 2008. Lomé. Dynamiques d’une ville africaine. Karthala, Paris.

Godard, X., 2013. Sustainable Urban Mobility in 'Francophone' Sub-Saharan Africa. Thematic study prepared for Sustainable Urban Mobility: Global Report on Human Settlements 2013. http://unhabitat.org/wpcontent/uploads/2013/06/GRHS.2013.Regional.Francophone.Africa.pdf (accessed 30.10.2015)

Goodfellow, T., Titeca, K., 2012. Presidential intervention and the changing "politics of survival” in Kampala's informal economy. Cities 29(4), 264-270.

Guézéré, A., 2008. Oléyia (taxi moto) : acteurs et usagers d'un mode de transport artisanal récent à Lomé. $\mathrm{PhD}$ Thesis. Université de Lomé, Lomé.

Guézéré, A., 2012. Territoires des taxis-motos à Lomé : de la pratique quotidienne à la recomposition des espaces urbains et des liens sociaux. Géographie, économie, société 14(1), 53-72.

Howe, J., 2003. "Filling the middle”: Uganda's appropriate transport services. Transport Reviews 23(2), 161-176.

Howe, J., Davis, A., 2002. Boda boda: Uganda's rural and urban low-capacity transport services. In: Godard, X., Fatounzoun, I. (eds), Urban Mobility for All. Proceedings of CODATU 10. A.A. Balkema Publishers, Lisse (Netherlands), pp. 235-240.

Kamuhanda, R., Schmidt, O., 2009. Matatu: a case study of the core segment of the public transport market of Kampala, Uganda. Transport Reviews 29(1), 129-142.

Kisaalita, W.S., Sentongo-Kibalama, J., 2007. Delivery of urban transport in developing countries: the case for the motorcycle taxi service (boda-boda) operators of Kampala. Development Southern Africa 24(2), 345-357.

Konings, P., 2006. Solving transportation problems in African cities: innovative responses by the youth in Douala, Cameroon. Africa Today 53(1), 35-50.

Lopes, C.M., 2010. Dinâmicas do associativismo na economia informal: os transportes de passageiros em Angola. Análise Social XLV(195), 367-391.

Mahlstein, M., 2009. Shaping and being shaped: the regulation of commercial motorcycle operation and social change in Calabar, Nigeria. MA Thesis. University of Basel, Basel.

Meagher, K., 2013. Informality, religious conflict, and governance in northern Nigeria: economic inclusion in divided societies. African Studies Review 56(3), 209-234.

Menzel, A., 2011. Between ex-combatization and opportunities for peace: the double-edged qualities of motorcycle-taxi driving in urban postwar Sierra Leone. Africa Today 58(2), 96-127.

Morice, A., 1981. Les vélos de Kaolack. Cahiers d'Etudes Africaines 21(81-82), 197-210.

Mutiso, W., Behrens, R., 2011. "Boda Boda" bicycle taxis and their role in urban transport systems: case studies of Kisumu and Nakura, Kenya. http://repository.up.ac.za/handle/2263/17308 (accessed 11.6.12).

Ngabmen, H., Godard, X., 1998. L'expérience des taxi-motos en Afrique de l'ouest: à la croisée des logiques économiques, sociales et environnementales. In: Freeman, P., Jamet, Ch. (ed.), Urban Transport Policy. A Sustainable Development Tool. Proceedings of CODATU 8. A.A. Balkema Publishers, Rotterdam, pp. 499503.

Ngabmen, H., Habyarimana, M., Eboumbou Jemba, C., 2000. Etude exploratoire sur les taxis-motos dans les villes africaines. Les “ bend skin” de Douala. Groupe Interdisciplinaire d'Etudes et de Recherche sur les Transports (Giret), Rapport pour le Ministère français des Affaires Etrangères.

Nkede Njie, L., 2012. The socio-cultural impact of the introduction of motorbike taxis in the rural community of Tombel, South West region, Cameroon. Master Thesis. Université de Yaoundé 1, Yaoundé.

Nwagwu, W., Olatunji, O., 2012. Life saving information behaviours of commercial motorcyclists in a metropolitan city in Nigeria. Libri 62(3), 259-275.

Ogalama Yabo, G., Nambang, M., Adognon, K., 2000. Etude exploratoire sur les taxis-motos dans les villes africaines : Le cas de la ville de Lomé. SITRASS-EAMAU.

Ogunrinola, I.O., 2011. Informal self-employment and poverty alleviation: empirical evidence from motorcycle taxi riders in Nigeria. International Journal of Economics and Finance 3(2), 176-185. 
Ogunsanya, A.A., Galtima, M., 1993. Motorcycle in public passenger transport service in Nigeria: case study of Yola town. In: Ikya, S.G. (ed), Urban Passenger Transportation in Nigeria. Heinemann Educational Books, Ibadan, pp. 190-207.

Olubomehin, O.O., 2012. The development and impact of motorcycles as means of commercial transportation in Nigeria. Research on Humanities and Social Sciences 2(6), 231-239.

Oteng-Ababio, M., Agyemang, E., 2012. Virtue out of necessity? Urbanisation, urban growth and Okada services in Accra, Ghana. Journal of Geography and Geology 4(1), 148-162.

Oyesiku, K.O., 2001. City poverty and emerging mobility crisis: The use of motorcycle as public transport in Nigerian cities. In: Proceedings of the 9th World Conference of Transport Research, Seoul.

Pah Forsther, M., 2011. No work, no peace: livelihoods of ex-combatants in Monrovia, Liberia. Master Thesis. University of Tromso, Tromso.

Panier, E., 2012. L'État et les relations de travail au Togo. PhD Thesis. Université Bordeaux IV - Montesquieu, Bordeaux.

Peters, K., 2007. From weapons to wheels: young Sierra Leonean ex-combatants become motorbike taxi-riders. Journal of Peace, Conflict and Development 10, 1-23.

PNUD Togo, 2012. Togo. Profil de pauvreté 2006-2011. PNUD, Lomé. http://www.tg.undp.org/content/dam/togo/docs/programme/Rapports/TGO-profil-pauvret\%C3\%A9-20062011.pdf (accessed 1.7.15).

Porter, G., Blaufuss, K., Owusu Acheampong, F., 2007. Youth, mobility and rural livelihoods in sub-Saharan Africa: perspectives from Ghana and Nigeria. Africa Insight 37(3), 420-431.

Quénot-Suarez, H., 2012. Quand les embouteillages «créent » la ville. L’influence de la congestion sur la structure et l'économie urbaines à Accra (Ghana). http://www.ifri.org/downloads/embouteillagesaccrahqs102012.pdf (accessed 10.29.12).

Rollason, W., 2013. Performance, poverty and urban development: Kigali's motari and the spectacle city. Afrika Fokus 26(2), 9-29.

Sadou, A., 2007. Les taxis-motos et l'insécurité urbaine dans le nord Cameroun. Le cas de la ville de Ngaoundéré. Conference Le taxi, solution d'avenir pour les mobilités urbaines, Institut pour la Ville en Mouvement, Lisbonne.

Sahabana, M., 2006. Les motos-taxis à Douala et leur perception par les pouvoirs publics : entre tolérance d'un secteur pourvoyeur d'emplois et de transport et volonté d'éradiquer une activité incontrôlable. http://www.euromedina.net/bibliotheque_fichiers/VC_Auf_TexteSahabana.pdf (accessed 7.13.14).

Sietchiping, R., Permezel, M.J., Ngomsi, C., 2012. Transport and mobility in sub-Saharan African cities: an overview of practices, lessons and options for improvements. Cities 29(3), 183-189.

Simone, A., 2005. Urban circulation and the everyday politics of African urban youth: the case of Douala, Cameroon. International Journal of Urban and Regional Research 29(3), 516-532.

SITRASS, 2001. Profitability and financing of urban public transport microenterprises in Sub-Saharan Africa. An overview of the regional study conducted in Abidjan, Bamako, Harare, and Nairobi. The World Bank. http://www.ssatp.org/en/publication/profitability-and-financing-urban-public-transport-microenterprises-subsaharan-africa (accessed 6.3.13).

Sumner, S.A., Pallangyo, A.J., Reddy, E.A., Maro, V., Pence, B.W., Lynch, C., Turner, E.L., Egger, J.R., Thielman, N.M., 2014. Effect of free distribution of safety equipment on usage among motorcycle-taxi drivers in Tanzania. A cluster randomised controlled trial. Injury 45(11), 1681-1686. 